\title{
Vase Life Studies on Cut Foliages under Shevaroy Condition of Eastern Ghats
}

\author{
M. Anand ${ }^{1 *}$, A. Sankari ${ }^{2}$ and K. Kayalvizhi ${ }^{3}$ \\ ${ }^{1}$ Horticultural Research Station, Yercaud, India \\ ${ }^{2}$ Department of Vegetable Science, HC \& RI, TNAU, Coimbatore, India \\ ${ }^{3}$ Dept. of Horticulture, Institute of Agriculture, TNAU, Kumulur-621 712, India \\ *Corresponding author
}

\section{A B S T R A C T}

\begin{tabular}{|l|}
\hline K e y w o r d s \\
Cut stems, Sucrose, \\
$\begin{array}{l}\text { Silver Nitrate and } \\
\text { Packing materials }\end{array}$ \\
\hline Article Info \\
\hline $\begin{array}{l}\text { Accepted: } \\
\text { 04 August 2020 } \\
\text { Available Online: } \\
\text { 10 September } 2020\end{array}$ \\
\hline
\end{tabular}

Keywords

Cut stems, Sucrose, Silver Nitrate and Packing materials

Post-harvest studies were attempted using pulsing and simulated
transportation on vase life of 29 ornamental cut foliages under Shevaroy
hills at Horticultural Research Station, Yercaud. Holding solution
containing Sucrose $5 \%+\mathrm{AgNO}_{3} 50 \mathrm{ppm}$ significantly increased vase life
of Dracaena fragrans 'Massangeana', Heliconia rostrata, Philodendron
red emerald and Dracaena fragrans 'lemon lime'. Pulsing solution
containing Sucrose 5\%+ AgNO $100 \mathrm{ppm}$ significantly increased vase life
of Cordyline chocolate queen, Nephrolepis cordifolia, Cordyline terminalis
and Cordylne compacta. The study also revealed that vase life durations
ranged from 6.00 to 15.00 days.

\section{Introduction}

Cut greens are an important component of the floricultural industry, largely used for decoration as filler in floral compositions. They provide freshness and colour variety to arrangements and bouquets (Pacifici et al., 2007). Foliage plants include all plants grown for their attractive leaves rather than for flowers and fruits. In general horticultural terms, however plants are those with attractive foliage and flowers that are able to survive and grown indoors. Foliage plants, in common terminology, are called house plants.
The cut foliage industry in Florida started in the 1980s when growers started producing Asparagus sp for shipment to northern markets (Manning, 1984). Nowadays, cut flowers and foliage occupy an important position in the local and foreign markets, due to its importance as a source of national income.

There are suitable environmental conditions for the production of flower and foliage crops for domestic and export market. Cut foliage production has been increasing rapidly in recent years. Flowers and foliage plants are 
some of the most colourful and attractive horticultural plants. Some are used to decorate the rooms while others are used to beautify the areas around our homes and public building. The preservatives materials used as pulsing and holding solutions seemed to prolong longevity. In this study, some chemical preservatives i.e., citric acid or aluminum sulphate as a biocide alone on with sucrose were used to prolong vase life (Chen et al., 2004).

\section{Materials and Methods}

The present investigation was carried out at Horticultural Research Station, Tamil Nadu Agricultural University, Yercaud during 2012- 2014. The experimental site is situated between $11^{\circ} 04^{\prime \prime}$ to $11^{\circ} 05^{\prime \prime}$ North latitude and $78^{\circ} 05^{\prime \prime}$ to $78^{\circ} 23^{\prime \prime}$ East longitude and at an altitude of $1500 \mathrm{~m}$ above Mean Sea Level.

The average minimum and maximum temperature of the area were $12.4^{\circ} \mathrm{C}$ and $31.0^{\circ} \mathrm{C}$ respectively. The soil is laterite in texture with 0.5 to $1.5 \mathrm{~m}$ depth. The experiment was laid out in a Randomized Block Design with three replication. Planting of twenty nine cut foilages was made in $44 x$ $21 \mathrm{~m}$ with plant spacing $1 \times 0.8 \mathrm{~cm}$. Data was generated on vegetative characters at 30 day intervals. Vegetative characters like plant height, number of shoots, number of leaves, length of leaves, width of leaves, plant spread, stem girth and post harvest characters like Pulsing solutions, Holding solutions and packing studies.

The details of the treatments used are given below:

\section{Pulsing treatments}

$\mathrm{P}_{\mathrm{o}}-$ Filtered Water

$\mathrm{P}_{1}$ - Acidified Water ( $\left.\mathrm{pH} 3.5\right)$

$\mathrm{P}_{2}$ - Sucrose $5 \%$
$\mathrm{P}_{3}$ - Sucrose 5\%+ $\mathrm{AgNO}_{3}$ 50ppm

$\mathrm{P}_{5}$ - Sucrose 5\%+AgNO $100 \mathrm{ppm}$

\section{Holding treatments}

$\mathrm{H}_{\mathrm{o}}$ - Filtered Water

$\mathrm{H}_{1}$ - Acidified Water ( $\mathrm{pH} 3.5$ )

$\mathrm{H}_{2}$ - Sucrose $5 \%$

$\mathrm{H}_{3}$ - Sucrose $5 \%+\mathrm{AgNO}_{3} 25 \mathrm{ppm}$

$\mathrm{H}_{4-}$ Sucrose 5\%+ $\mathrm{AgNO}_{3} 50 \mathrm{ppm}$

\section{Packaging studies}

The foliage of different species were treated with the best pulsing solution and packed (both dry without any cotton plug and with a cotton plug at the petiole end) in cartons of $60 \times 30 \times 10 \mathrm{~cm}$ in bunches of twelve/carton.

The following lining materials were used along with control:

Print sheet

Polythene sheet

Polypropylene sheet

The data generated during the course of study was subjected to statistical analysis as prescribed by Panse and Sukhatme (2000).

\section{Results and Discussion}

Among the different holding solutions used, higher vase life was recorded in $\mathrm{H}_{4}$ (Sucrose $5 \%+\mathrm{AgNO}_{3} 50$ ppm) with 16.3 days. This was significantly superior to other holding treatments. Cut foliage treated with Sucrose $5 \%$, Sucrose $5 \%+\mathrm{AgNO}_{3} 25 \mathrm{ppm}$ treatment also showed a relatively longer vase life (15.9 days) (Table 1). Foresst (1991) also reported that pulsing cut Eucalyptus gunni with STS or 8 HQC did not lengthen the vase life. According to postharvest treatments for codiaeum cut stems showed highest vase life in 8-HQS and had no significant differences for preservatives and tap water. 8-HQS 
controlled microbial growth in the holding solution and helped to prolong vase life of cut stems (Hettiarachchi and Balas, 2005). The enhancement of vase life of cut foliages by using sucrose in combination with $\mathrm{AgNO}_{3} @$
20 and 40 ppm reported by Malakar et al., 2017. Wijayabandara et al., 2018 reported that the most effective vase solutions for Ophiopogon japonicus were sucrose 20 or 30 $\mathrm{g} / \mathrm{L}$ pulsing treatments for 24 hour.

Table.1 Effect of the holding solution on the cut foliages at Shevaroy condition

\begin{tabular}{|l|c|c|c|c|c|c|}
\hline Name of the species & $\mathbf{H}_{\mathbf{0}}$ & $\mathbf{H}_{\mathbf{1}}$ & $\mathbf{H}_{\mathbf{2}}$ & $\mathbf{H}_{\mathbf{3}}$ & $\mathbf{H}_{\mathbf{4}}$ & Mean \\
\hline Dracaena reflexa & 7.00 & 7.50 & 8.60 & 15.1 & 14.7 & 10.60 \\
\hline Cordyline tango & 7.00 & 7.50 & 12.2 & 13.4 & 13.7 & 10.70 \\
\hline Dracaena sanderiana & 6.50 & 7.20 & 12.6 & 14.5 & 16.1 & 11.40 \\
\hline Dracaena compacta & 6.20 & 6.30 & 11.7 & 14.1 & 15.7 & 10.80 \\
\hline $\begin{array}{l}\text { Dracaena reflexa'Song of } \\
\text { Jamaica' }\end{array}$ & 7.20 & 5.60 & 10.3 & 15.9 & 16.3 & 11.00 \\
\hline $\begin{array}{l}\text { Dracaena fragrans } \\
\text { 'Massangeana' }\end{array}$ & 8.40 & 7.30 & 11.5 & 15.0 & 15.5 & 11.50 \\
\hline Dracaena 'Purple compacta' & 7.10 & 6.10 & 11.5 & 12.9 & 12.9 & 10.10 \\
\hline Dracaena marginata & 5.20 & 5.40 & 10.4 & 14.5 & 15.2 & 10.10 \\
\hline Cordyline fruitcosa & 7.20 & 7.50 & 10.9 & 13.3 & 14.5 & 10.70 \\
\hline Philodendron xanadu & 7.90 & 6.40 & 11.9 & 12.9 & 14.4 & 10.70 \\
\hline Philodendron red emerald & 7.70 & 6.70 & 11.7 & 13.1 & 16.2 & 11.10 \\
\hline Anthurium andreanum & 6.40 & 6.50 & 11.3 & 15.0 & 15.5 & 10.90 \\
\hline Dracaena fragrans 'lemon lime' & 7.10 & 6.20 & 11.2 & 12.4 & 16.2 & 10.60 \\
\hline Aglaonema Crispum & 8.40 & 6.70 & 10.7 & 14.0 & 13.6 & 10.70 \\
\hline Cordylne compacta & 7.00 & 7.00 & 11.6 & 13.5 & 15.3 & 10.90 \\
\hline Cordyline negra & 6.40 & 6.60 & 11.4 & 12.3 & 14.1 & 10.20 \\
\hline Cordyline terminalis & 7.30 & 6.20 & 9.90 & 13.3 & 14.5 & 10.30 \\
\hline Dracaena reflexa var tropical & 6.50 & 6.60 & 11.3 & 13.6 & 14.5 & 10.50 \\
\hline Cordyline chocolate swirl & 6.90 & 5.70 & 13.4 & 14.7 & 15.2 & 11.20 \\
\hline Cordyline chocolate queen & 7.40 & 7.50 & 12.5 & 12.9 & 13.7 & 10.80 \\
\hline Nephrolepis cordifolia & 7.80 & 6.50 & 10.1 & 12.1 & 14.4 & 10.20 \\
\hline Nephrolepis falcate & 7.60 & 6.90 & 12.2 & 14.3 & 15.3 & 11.30 \\
\hline Philodendron green emerald & 7.70 & 6.00 & 12.1 & 14.1 & 15.4 & 11.10 \\
\hline Philodendron 'ceylone gold' & 6.50 & 5.90 & 11.9 & 10.0 & 13.4 & 9.50 \\
\hline Philodendron imbe 'variegata' & 6.30 & 6.80 & 11.4 & 15.3 & 15.1 & 11.00 \\
\hline Heliconia rostrata & 7.40 & 6.00 & 11.3 & 13.7 & 16.3 & 10.90 \\
\hline Asparagus sprengeri & 6.70 & 7.20 & 11.5 & 15.3 & 15.3 & 11.20 \\
\hline Asparagus setaceous & 7.3 & 5.8 & 11.3 & 13.6 & 15.5 & 10.70 \\
\hline Asparagus densiflorus & 5.7 & 6.4 & 10.0 & 12.7 & 14.1 & 9.80 \\
\hline & 0.40 & 0.36 & 0.70 & 1.10 & 0.74 & - \\
\hline & 0.81 & 0.72 & 1.40 & 2.21 & 1.49 & \\
\hline
\end{tabular}

$* \mathrm{H}_{\mathrm{o}}$ - Filtered Water $\mathrm{H}_{1}$ - Acidified Water $(\mathrm{pH} 3.5)$

$\mathrm{H}_{2}$ - Sucrose $5 \% \quad \mathrm{H}_{3}$ - Sucrose $5 \%+\mathrm{AgNO}_{3} 25 \mathrm{ppm}$

$\mathrm{H}_{4-}$ Sucrose $5 \%+\mathrm{AgNO}_{3} 50 \mathrm{ppm}$ 
Table.2 Effect of pulsing treatments on the cut foliage at Shevaroy condition

\begin{tabular}{|c|c|c|c|c|c|c|}
\hline Name of the species & $\mathbf{P}_{\mathbf{0}}$ & $\mathbf{P}_{1}$ & $\mathbf{P}_{2}$ & $\mathbf{P}_{3}$ & $\mathbf{P}_{4}$ & Mean \\
\hline Dracaena reflexa & 12.90 & 9.80 & 10.20 & 10.90 & 17.10 & 12.20 \\
\hline Cordyline tango & 10.40 & 10.50 & 11.50 & 10.80 & 18.30 & 12.30 \\
\hline Dracaena sanderiana & 9.10 & 9.00 & 9.70 & 9.20 & 19.70 & 11.30 \\
\hline Dracaena compacta & 9.60 & 9.80 & 9.60 & 9.70 & 16.80 & 11.10 \\
\hline Dracaena reflexa' Song of Jamaica' & 9.10 & 8.90 & 9.40 & 9.10 & 17.90 & 10.90 \\
\hline Dracaena fragrans 'Massangeana' & 10.4 & 9.00 & 12.90 & 10.80 & 19.00 & 12.40 \\
\hline Dracaena' Purple compacta' & 9.20 & 10.10 & 10.60 & 10.00 & 20.60 & 12.10 \\
\hline Dracaena marginata & 8.10 & 9.90 & 12.00 & 10.00 & 20.10 & 12.00 \\
\hline Cordyline fruitcosa & 8.60 & 8.20 & 9.10 & 8.70 & 19.70 & 10.90 \\
\hline Philodendron xanadu & 8.00 & 8.20 & 10.10 & 8.70 & 20.00 & 11.00 \\
\hline Philodendron red emerald & 9.20 & 8.90 & 11.30 & 9.80 & 17.90 & 11.40 \\
\hline Anthurium andreanum & 10.50 & 10.10 & 11.80 & 10.80 & 17.40 & 12.10 \\
\hline Dracaena fragrans 'lemon lime' & 9.30 & 11.70 & 12.70 & 11.20 & 16.50 & 12.30 \\
\hline Aglaonema Crispum & 8.40 & 10.10 & 12.30 & 10.30 & 15.80 & 11.40 \\
\hline Cordylne compacta & 8.50 & 10.40 & 10.10 & 9.70 & 19.50 & 11.60 \\
\hline Cordyline negra & 8.30 & 9.50 & 10.60 & 9.50 & 18.50 & 11.30 \\
\hline Cordyline terminalis & 8.30 & 9.50 & 10.80 & 9.50 & 19.40 & 11.50 \\
\hline Dracaena reflexa var tropical & 8.50 & 8.20 & 9.50 & 8.70 & 18.40 & 10.70 \\
\hline Cordyline chocolate swirl & 7.80 & 8.30 & 10.30 & 8.80 & 17.10 & 10.40 \\
\hline Cordyline chocolate queen & 8.70 & 10.40 & 11.80 & 10.30 & 20.30 & 12.30 \\
\hline Nephrolepis cordifolia & 8.90 & 8.90 & 11.20 & 9.70 & 19.30 & 11.60 \\
\hline Nephrolepis falcate & 8.80 & 8.30 & 10.50 & 9.20 & 17.10 & 10.80 \\
\hline Philodendron green emerald & 8.20 & 7.80 & 10.30 & 8.80 & 19.60 & 10.90 \\
\hline Philodendron 'ceylone gold' & 7.40 & 8.30 & 10.80 & 8.80 & 17.00 & 10.40 \\
\hline Philodendron imbe 'variegata' & 7.70 & 8.20 & 11.30 & 9.10 & 17.50 & 10.70 \\
\hline Heliconia rostrata & 7.90 & 8.10 & 13.30 & 9.80 & 19.90 & 11.80 \\
\hline Asparagus sprengeri & 7.60 & 8.50 & 10.50 & 8.90 & 17.50 & 10.60 \\
\hline Asparagus setaceous & 8.00 & 9.20 & 12.30 & 9.90 & 17.90 & 11.50 \\
\hline Asparagus densiflorus & 7.50 & 7.90 & 9.50 & 8.30 & 18.60 & 10.30 \\
\hline SEd & 0.48 & 0.55 & 0.61 & 0.88 & 0.74 & - \\
\hline $\mathrm{CD}(\mathrm{P}=0.05)$ & 0.97 & 1.11 & 1.23 & 1.77 & 1.49 & - \\
\hline
\end{tabular}

$\mathrm{P}_{\mathrm{o}}$ - Filtered Water $\mathrm{P}_{1}$ - Acidified Water $(\mathrm{pH} 3.5)$

$\mathrm{P}_{2}$ - Sucrose 5\% $\quad \mathrm{P}_{3}$ - Sucrose $5 \%+\mathrm{AgNO}_{3} 50 \mathrm{ppm}$

$\mathrm{P}_{4}$ - Sucrose $5 \%+\mathrm{AgNO}_{3} 100 \mathrm{ppm}$ 
Table.3 Effect of packing / lining materials on cut foliages at Shevaroy condition

\begin{tabular}{|l|c|c|c|c|}
\hline Name of the species & $\begin{array}{c}\text { Print } \\
\text { Sheet }\end{array}$ & $\begin{array}{c}\text { Polythene } \\
\text { Sheet }\end{array}$ & $\begin{array}{c}\text { Polypro- } \\
\text { line sheet }\end{array}$ & Mean \\
\hline Dracaena reflexa & 4.50 & 7.00 & 7.90 & 6.40 \\
\hline Cordyline tango & 4.50 & 6.70 & 8.00 & 6.40 \\
\hline Dracaena sanderiana & 6.50 & 6.90 & 8.10 & 7.10 \\
\hline Dracaena compacta & 6.40 & 7.80 & 8.40 & 7.50 \\
\hline Dracaena reflexa'Song of Jamaica' & 6.20 & 7.10 & 9.00 & 7.40 \\
\hline Dracaena fragrans 'Massangeana' & 13.60 & 16.50 & 16.60 & 15.60 \\
\hline Dracaena 'Purple compacta' & 5.90 & 7.40 & 9.30 & 7.50 \\
\hline Dracaena marginata & 11.30 & 12.10 & 14.20 & 12.60 \\
\hline Cordyline fruitcosa & 11.40 & 12.00 & 12.40 & 11.90 \\
\hline Philodendron xanadu & 10.70 & 12.00 & 12.90 & 11.80 \\
\hline Philodendron red emerald & 11.10 & 11.10 & 13.10 & 11.80 \\
\hline Anthurium andreanum & 9.30 & 9.80 & 10.90 & 10.00 \\
\hline Dracaena fragrans 'lemon lime' & 6.90 & 8.50 & 10.90 & 8.80 \\
\hline Aglaonema Crispum & 13.50 & 14.30 & 15.10 & 14.30 \\
\hline Cordylne compacta & 10.30 & 11.00 & 12.30 & 11.20 \\
\hline Cordyline negra & 10.90 & 11.70 & 13.40 & 12.00 \\
\hline Cordyline terminalis & 11.90 & 12.30 & 14.80 & 13.00 \\
\hline Dracaena reflexa var tropical & 8.40 & 9.90 & 12.00 & 10.10 \\
\hline Cordyline chocolate swirl & 9.50 & 11.30 & 12.30 & 11.00 \\
\hline Cordyline chocolate queen & 9.40 & 11.10 & 12.50 & 11.00 \\
\hline Nephrolepis cordifolia & 12.30 & 12.70 & 13.50 & 12.90 \\
\hline Nephrolepis falcate & 10.70 & 11.30 & 12.60 & 11.50 \\
\hline Philodendron green emerald & 13.80 & 14.80 & 13.70 & 14.10 \\
\hline Philodendron 'ceylone gold' & 12.90 & 13.50 & 14.80 & 13.70 \\
\hline Philodendron imbe 'variegata & 11.70 & 11.90 & 12.90 & 12.20 \\
\hline Heliconia rostrata & 11.80 & 13.50 & 12.40 & 12.60 \\
\hline Asparagus sprengeri & 9.80 & 10.60 & 11.30 & 10.60 \\
\hline Asparagus setaceous & 10.60 & 10.80 & 11.90 & 11.10 \\
\hline Asparagus densiflorus & 10.10 & 10.30 & 12.50 & 11.00 \\
\hline SEd & $\mathbf{0 . 5 8}$ & $\mathbf{0 . 5 8}$ & $\mathbf{0 . 6 3}$ & \\
\hline CD (P= 0.05) & $\mathbf{1 . 1 6}$ & $\mathbf{1 . 1 6}$ & $\mathbf{1 . 2 6}$ & \\
\hline & & & & \\
\hline
\end{tabular}

It is evident from Table 2 that significant effect on number of roots was noticed under the treatment $\mathrm{P}_{4}$ (Sucrose 5\% $+\mathrm{AgNO}_{3} 100$ ppm) with 20.60 days. This was significantly superior to other pulsing solutions. It was followed by $\mathrm{P}_{2}$ (Sucrose 5\%) with 13.30 days. Nooh et al., (1986) on the other hand reported addition of 8 -HQC and Sucrose to the holding solution of Rusus hypophyllum and Nephrolepis exceltata was more effective than tap water. Criley and Parvin (1993) conducted trails with 21 different cut foliages and found only two genera to be benefited by the use of floral preservatives. In the holding solutions like distilled water and acidified water species 
like Codiaeum varigatum rooted. Stamps and Osborne (2003) reported rooting of croton leaves in water. They also reported the use of floral preservatives to be determined in the longevity of croton leaves. Elhindi (2012) revealed that in the cut sweet pea (Lathyrus odoratus L.) flowers held in the solution containing sucrose +8 hydroxyquinoline (Suc+HQS) was more effective in promoting absorption rate, achieved greater maximum fresh mass, had better water balance for a longer period, extended the vase life (up to $17 \mathrm{~d}$ ), and delayed degradation of chlorophylls.

Average vase life for individual harvest ranged from 7.9 d for Dracaena reflexa and $8.0 \mathrm{~d}$ for Cordyline tango to $14.80 \mathrm{~d}$ for Philodendron 'ceylone gold' and Cordyline terminalis (Table 3). Dracaena reflexa and Dracaena sanderiana frequently had the shortest vase life across all harvests. Packing should protect the cut foliage from any physical damage, water loss and detrimental external conditions during transport. The material used for packing helps to regulate water loss and respiration. Packing the foliage using wet cotton plugs at the petiole end was found to give a better result, which was in conformity with the results of the study, by Nowak and Rudnicki (1990) reported that mature stems of Asparagus setaceous and mature leaves of Dracaena sp, Cordyline terminalis kept well when packed in plastic bags or plugging with wet cotton and packing without lining material was enough to transport the foliage.

In conclusion the increasing vase life is the key issue in the post harvest management of cut foliages. It appears that chemicals used for enhancing vase life, improve the water uptake of cut foliages by reducing the vascular blockage and ultimately improving the vase life. From the results obtained in this experiment, it could be concluded that effect of pulsing treatments and holding treatments $\left(\mathrm{P}_{5}\right.$ - Sucrose $5 \%+\mathrm{AgNO}_{3} 100$ ppm and $\mathrm{H}_{4}$ - Sucrose $5 \%+\mathrm{AgNO}_{3} 50 \mathrm{ppm}$ ) could significantly improve the keeping quality of cut foliages.

\section{References}

Chen, D. S., N.H. Li, J.M. Wang, Y.X. Ding and X.J. Wang. 2004. Effect of calcium chloride on preservation of cut flowers of Gerbera hybirda. Acta Botanic Yunnanica, 26 (3): 345.448

Criley, R. A. and P.E. Parvin. 1993. New cut foliages from Australia, New Zealand and South Africa. Acta.Horticulturae 337:95-98.

Elhindi, K. M. 2012. Effects of postharvest pretreatments and preservative solutions on vase life longevity and flower quality of sweet pea (Lathyrus odoratus L.). Photosynthetica 50 (3): 371-379.

Forrest, M. 1991. Post- harvest treatment of cut foliages. Acta Hort. 298: 255-261.

Hettiarachchi, M.P. and J. Balas. 2005. Croton (Codiaeum Varieatum (L.) Blue 'Excellent'): An evaluation of foliage plants performance after shipment and of vase water treatments to maintain vase life. Acta Hort. 669: 342-349.

Malakar,M., Pinaki Acharyya and Sukanta Biswas. 2017. Effect of Certain Chemicals on Post Harvest Life of Some Cut Foliages. International Journal of Agriculture, Environment and Biotechnology. 10(2): 199-207.

Manning, R. D. 1984. From orange to green "gold": the roots of the asparagus fern industry in Florida. Florida Historical Quarterly 62: 464-484.

Nooh, A. E., E. Kiey and M.K. Hattab. 1986. Studies on the keeping quality of cut green Ruscus hypoglossum L. and Nephrolepis exaltat Schott. Acta 
Horticulturae 181: 223-229.

Nowak, J. and R.M. Rudnickii. 1990. Post Harvest Handling and Storage of Cut Flowers, Florist Greens and Potted plants. Chapman and Hall India, Madras. Pp. 210.

Olsen, S. R., C.L. Cole, F.S. Watanbe and D.A. Dean. 1954. Estimation of available phosphorus in soils by extraction with Sod. Bicarbonate. U.S.D.A. Cinc. Pp. 339.

Pacifici, S., A. Ferrante, A. Mensuali-Sodi, G. Serra, 2017. Postharvest physiology and technology of cut eucalyptus branches: a review. Agr. Med. 137, 124-131.
Panse VG, Sukhatme PV. 2000. Statistical methods for agricultural workers. Publication and Information Division of ICAR, New Delhi,

Stamps, R. H. and L.S. Osborne. 2003. Croton production and use. edis.ifas.ufl.edu/-BODY/EP106-25K.

Wijayabandara, S. M. K. H., J. W. Damunupola, S. A. Krishnarajah, W. A. M. Daundasekera and D. S. A. Wijesundara. 2018. Effect of different vase solutions on postharvest longevity of cut foliage Ophiopogon japonicas. Ceylon Journal of Science 47(2): 195-199.

\section{How to cite this article:}

Anand, M., A. Sankari and Kayalvizhi, K. 2020. Vase Life Studies on Cut Foliages under Shevaroy Condition of Eastern Ghats. Int.J.Curr.Microbiol.App.Sci. 9(09): 34-40.

doi: https://doi.org/10.20546/ijcmas.2020.909.004 